\title{
Sermaye ve Sahiplik Yapısının Firma Performansına Etkisi: Borsa İstanbul Turizm Endeksi Uygulaması ${ }^{1}$ (Araştırma Makalesi)
}

The Effect of Capital and Ownership Structure on Firm's Performance: An Application on Borsa Istanbul Tourism Index

Doi: 10.29023/alanyaakademik. 872410

\section{Fatih KONAK}

Doç. Dr., Hitit Üniversitesi İktisadi ve İdari Bilimler Fakültesi Işsletme Bölümü fatihkonak@hitit.edu.tr

Orcid No: 0000-0002-6917-5082

\section{Diler TÜRKOĞLU}

Doktora ögrencisi, Hitit Üniversitesi Sosyal Bilimler Enstitüsü, İşletme Anabilim Dalı diler.turkoglu@samsun.edu.tr

Orcid No: 0000-0001-5247-1590

Bu makaleye atıfta bulunmak için: Konak, F. \& Türkoğlu, D. (2022). "Sermaye ve Sahiplik Yapısının Firma Performansina Etkisi: Borsa İstanbul Turizm Endeksi Uygulaması”, Alanya Akademik Bakıs,, 6(1), Sayfa No. 1571-1586.

\begin{tabular}{|c|c|}
\hline & ÖZET \\
\hline $\begin{array}{l}\text { Anahtar kelimeler: } \\
\text { BIST Turizm Endeksi, } \\
\text { Sahiplik Yapısı, } \\
\text { Sermaye Yapısl. }\end{array}$ & $\begin{array}{l}\text { Hem şirketlerin iç dinamikleri hem de piyasa katılımcıları açısından } \\
\text { bakıldığında firma değerinin belirlenebilmesi ya da bu değer üzerine etki } \\
\text { eden faktörlerin tespiti büyük önem taşımaktadır. Firma değerinin tespitinde } \\
\text { optimal sermaye yapısının ortaya çıarllması ve bunun yanı sıra sahiplik } \\
\text { vapısının etkilerinin göz önüne alınması, özellikle karar alma asamasında }\end{array}$ \\
\hline $\begin{array}{l}\text { Makale Geliş Tarihi: } \\
\text { 01.02.2021 } \\
\text { Kabul Tarihi: } \\
\text { 12.01.2022 }\end{array}$ & $\begin{array}{l}\text { yapısının etkilerinin göz önüne alınmasl, özellikle karar alma aşamasında } \\
\text { dikkat edilmesi gereken önemli faktörlerden bazıları olarak karşımıza } \\
\text { çımaktadır. Bu doğrultuda çalışmada, firmaların sahiplik ve sermaye } \\
\text { yapısının birlikte ele alınıp firma performansı üzerindeki etkilerinin } \\
\text { araştırılması amaçlanmıştır. Araştırmada 2012-2018 yılları arasında Borsa } \\
\text { İstanbul Turizm Endeksi nde faaliyet gösteren } 9 \text { firmanın verilerinden } \\
\text { faydalanılmıstır. Nihai olarak, Borsa İstanbul Turizm Endeksi'nde yer alan } \\
\text { firmaların finansal performans göstergeleri üzerinde hem sahiplikyapılarının } \\
\text { hem de sermaye yapılarının farklı düzey ve yönlerde etkiye sahip olduğu } \\
\text { neticesi iddia edilmektedir. }\end{array}$ \\
\hline
\end{tabular}

Keywords:

BIST Tourism Index,

Ownership Structure,

Capital Structure.

\begin{abstract}
Considering both the internal dynamics of the companies and the market participants, it is of great importance to determine the value of the firm or to determine the factors that affect this value. In determining the firm's value, revealing the optimal capital structure as well as considering the effects of ownership structure are some of the important factors that should be taken into consideration especially during the decision-making phase. In this
\end{abstract}

\footnotetext{
${ }^{1}$ Bu çalışma, Uluslararası Sosyal Bilimler ve Eğitim Bilimleri Sempozyumu'nda yazarlar tarafindan sözlü olarak sunulan özet bildirinin düzenlenmiş ve genişletilmiş son halidir.
} 
framework, the research aimed to examine the effects of ownership and capital structure of firms on firm performance by considering them together. The data of 9 companies listed in the BIST Tourism Index between 2012 and 2018 were used in this context. According to the findings obtained, it has been concluded that both ownership structures and capital structures have effects on the financial performance indicators of the companies listed in the BIST Tourism Index at different levels and directions.

\section{GİRIŞ}

Bir finans yöneticisinin temel amacı firmanın cari piyasadaki değerinin maksimize edilmesidir ve firma değeri maksimizasyonunda öne çıkan en büyük etkenlerden biri sermaye yapısıdır. Dolayısıyla işletmenin sermaye yapısı belirlenirken optimum yapıyı oluşturmak için sermaye yapısını etkileyen faktörleri göz önünde bulundurmak büyük önem arz etmektedir. Başka bir deyişle sermaye yapısının belirlenmesi hissedarların çıkarını en üst düzeyde tutacak şekilde olmalıdır. Çünkü belirlenen sermaye yapısı firmanın değerlemesinde son derece büyük öneme sahiptir. Oluşturulan sermaye yapısı kombinasyonlarıyla firmanın ağırlıklı ortalama sermaye maliyeti belirlenerek firmanın 1skonto oranı tespit edilmektedir. Belirlenen bu 1skonto oranıyla firmanın kredibilitesi ortaya çıkacak, başka deyişle riski tespit edilerek hem hissedarların hem de firmaya borç verecek olan kurum ve kişilerin kararlarında son derece etkili olacağ1 öngörülmektedir. Bir şirketin sermaye yapısının firma değerini doğrudan etkilediği bu varsayıma göre firma değerinin belirlenebilmesi ve bu değer üzerinde etki eden faktörlerin tespiti için sermaye yapısının yanı sıra sahiplik yapısının da ele alınarak bir değerlendirme yapılması gerektiği düşünülmektedir. Sermaye ve sahiplik yapısı ile alakalı kararlarının veya mevcut durumunun ilgili yazında görülen değişkenler üzerinde farklı düzeylerde etkisinin olduğu söylenebilir. Sahiplik yapısı aile işletmeleri, en büyük ortağın sermayedeki payı, en büyük 2 ortağın sermayedeki payları, en büyük 3 ortağın sermayedeki payları, yabancı ortak sermaye payı, halka açıklık oranı, kurumsal ortağın sermayedeki payı ve kamu sahipliği gibi sahiplik çeşitlerinden oluşmaktadır.

Bu çalışmada BİST Turizm Endeksi'nde 2012-2018 yılları arasında faaliyet gösteren firmaların sahiplik ve sermaye yapısının değişkenlere olası etkilerinin tespit edilmesi amaçlanmıştır. Söz konusu firmaların Kamu Aydınlatma Platformundan elde edilen verilerinden faydalanılarak, değerlendirmeye tabi tutulan değişkenlerin etkileri yorumlanmıştır. Sahiplik ve sermaye yapısının firma performansına olan etkilerinin tespit edilmesi amaçlanmıştır. Performans ölçütü olarak Aktif Karlılık, Özkaynak Karlılığı ve Tobins’ Q değişkenleri dikkate alınmıştır. Varlıkların kazanma gücü olarak da ifade edilen Aktif Karlılık (ROA), işletmenin net kar marjına ve her bir liralık varlıkta kaç liralık satış yapıldığına bağlı olmaktadır (Aydın vd., 2017:115). Benzer olarak Özkaynak Karlılı̆̆ı (ROE), firmanın bir birimlik özkaynaktan elde ettiği net karı ifade etmektedir (Cornett vd., 2016: 57). Sermaye yatırım kararlarına ilişkin bir gösterge olarak ele alınan Tobins' Q ise piyasa değerinin yüksek kar oranları nedeniyle yerine koyma maliyetlerini aştığında firmaların hareketlerinin büyüme yönünde olacağını göstermektedir (Çelik,2018: 464).

Tüm bu değişkenlere olası etkinin tespiti amacıyla Panel Veri Analizi yöntemi uygulanmıştır. Kullanılacak olan ekonomik veriler, şirketlerin internet siteleri ve Kamu Aydınlatma Platformundan elde edilmiş olup bu veriler Hausman Testi ile analiz edilmiştir. Çalışmada literatür bilgisine yer verildikten sonra sahiplik ve sermaye yapıları ile ilgili teorik bilgilere 1572 
değinilmiştir. Verilen bu bilgilerin devamında amaç, veri seti ve yöntem hakkında açıklamalar yapılmış, analizde kullanılacak değişkenlerle ilgili bilgi verildikten sonra, araştırmanın bulgu ve sonuçları değerlendirilmiştir.

\section{SAHIPLLIK YAPISI VE SERMAYE YAPISI}

Finans yöneticisinin, firmanın piyasa değerini maksimum kılma amacıyla vereceği kararlar firmanın hissedarlarının servetlerini artırma yolunda son derece önemlidir. Bu kararların alınmasında önemli etkenlerden biri son zamanlarda finans literatüründe oldukça ilgi çeken sahiplik yapısıdır. Sahiplik yapısı kapsamında özellikle ortakların vereceği kararlar firmanın faaliyetlerinin sürdürülmesinde çok önemli roller oynamaktadır. Sahiplik yapısının etkinliği işletmenin sürekliliğinin sağlanması, karlılığın artırılması, rakiplerine karşı üstünlük elde etmesi ve söz konusu işletmenin piyasa değerinin artırılması açısından büyük önem taşımaktadır (Önem ve Demir, 2015: 31). Firma değerinin arttırılmasında bu derece etkin olan sahiplik yapısı genellikle, yönetsel sahiplik, yabancı sahiplik, aile sahipliği, devlet sahipliği, büyük pay sahipliği ya da kurumsal sahiplik şeklinde incelenip değerlendirilmektedir (Şamiloğlu ve Ünlü, 2010: 66). Bu çeşitlilikle birlikte sahiplik yapısı her firma için değişkenlik göstermektedir. Sahipliğin tabana yayılması kapsamında firmalardaki ortak sayısının fazla olması, finansal piyasalarda tercih edilen bir durumdur.

Sahiplik yapısı öz sermayenin ortaklara dağılım oranını, hissedarların özellikle yönetimle olan ilişkisini, şirketin kontrolünü elinde bulundurup bulundurmadığını ifade etmekle birlikte (Ege ve Topaloğlu, 2017: 471) yöneticiler ve hissedarlar arasında oluşması muhtemel vekâlet maliyetleri kurumsal yönetim açısından büyük önem arz etmektedir (Yılgör ve Yücel, 2012: 42). Diğer bir ifadeyle, sahiplik yapısı işletme sahiplerinin, yöneticilerin ve işletmeye borç verenlerin çıkarlarını maksimize etmek ve hedefleri doğrultusunda beklentilerini karşılamak amacıyla işletme kararlarını etkileyebilmektedir (Erdoğan, 2016: 161). Elbette sahiplik yapısı bir firmanın karar mekanizmasının çalışmasında tek başına etken olmamaktadır. $\mathrm{Bu}$ mekanizmanın etkinliğinde birçok faktör olmakla birlikte en önemlilerinden biri olarak tanımlanabilecek sermaye yapısıdır.

Sahiplik yapısı ve sermaye yapısı arasındaki ilişki, kurumsal yönetim ile firma performansı arasındaki bağlantıyı vurgulaması açısında çok önemlidir (Margaritis ve Psillaki, 2008:7). Bunun yanı sıra firmanın risk ve getiri oranları arasındaki dengeyi sağlayan, sermaye maliyetlerini en aza indirgemeye odaklanan ve işletmenin piyasa değerini maksimum kılan yapı olarak tanımlanabilen optimal sermaye yapısı, firma için en uygun borç ve özkaynak bileşimini sağlamalıdır (Aydın vd., 2015: 278). Bu tanımdan yola çıkarak, hissedarların kazancını ve firmanın değerini etkileyen en önemli kararlardan birinin sermaye yapısı olduğu aşikardır (Shahar vd., 2016: 36). Çünkü borç miktarının ve özkaynak oranının belirlemesinde firma yöneticileri, firmanın hissedarları için ayrılacak nakdin maksimize edilmesi ile kısa veya uzun vadeli borcun temerrüde düşme riski arasında bir seçim yapmak durumunda kalabilmektedirler (Cornett vd., 2016: 245). İşte bu durumda karar verilmesi gereken asıl husus optimal sermaye yapısının nasıl sağlanacağıdır. Optimal sermaye yapısı için birçok görüş bulunmaktadır. Bunlardan Net Gelir Yaklaşımı, Net Faaliyet Yaklaşımı ve Geleneksel Yaklaşım klasik yaklaşımlar olarak adlandırılırken, Modigliani ve Miller'in 1958 yılında öne sürmüş olduğu İlgisizlik Teorisi oldukça eleştiri almıştır. Modigliani ve Miller yaklaşımlarının varsayımlarını daha realist bir ortama yakınlaştırarak, bu konuda yapılan çalışmaların temelini oluşturmayı başarmışlardır (Sayılgan ve Uysal, 2011: 103). Sermaye yapısını açıklayan teorik yaklaşımlar aşağıda sıralanmıştır. 
Modigliani ve Miller İlgisizlik Teorisi: Modigliani ve Miller yapmış oldukları çalışmalarında önce vergisiz bir piyasa için daha sonra da kurumlar vergisinin bulunduğu bir piyasa için sermaye yapısı önerilerinde bulunmuş ve teorik olarak şirketlerdeki borcun faiz vergi kalkanı sayesinde firma değerini artırdığını tespit etmişlerdir (Shahar vd., 2015: 37). Ayrıca Modigliani ve Miller belirli varsayımlar altında işletme değerinin sermaye yapısından bağımsız olduğunu ve dolayısıyla finansal kaldıraç derecesinin işletmenin sermaye maliyetini değiştirmeyeceğini öne sürmüşleridir. Bu önerme MM tarafından arbitraj olanaklarına ve sermaye piyasalarının tam olarak organize işlediği varsayımına dayandırmıştır (Aydın vd., 2015: 292).

Net Gelir Yaklaşımı: Bu yaklaşım, işletmelerin yalnızca borç kullanmakta olduğunu varsaymaktadır. İşlem maliyetleri ve ihraç maliyetlerinin, kurumlar vergisi ve gelir vergisinin hatta iflas maliyetlerinin göz ardı edildiği varsayıma göre işletme ne kadar borçlanırsa borçlansın, ortakların veya işletmeye borç verenlerin beklentileri değişmemektedir. Bu nedenle ortakların getiri beklentisi daha yüksektir. Diğer bir ifadeyle özkaynak maliyetleri, borç maliyetlerinden daha yüksektir (Sayılgan, 2019: 331). Varsayım, yabancı kaynak ile finansman oranının artmasının ağırlıklı ortalama sermaye maliyetini düşürmekte ve haliyle işletmenin değerini yükseltmekte olduğunu öne sürmektedir (Sayman, 2012:12).

Net Faaliyet Gelir Yaklaşımı: Optimal sermaye yapısının mümkün olmadığını savunan bu yaklaşımda, işletmelerin ağırlıklı ortalama sermaye maliyetinin değişmediği varsayılmaktadır, dolayısıyla işletmenin oluşturacağı sermaye yapısı işletme değeri ve işletmenin ağırlıklı ortalama sermaye maliyeti üzerinde hiçbir şekilde etkili olmayacaktır. Net faaliyet geliri yaklaşımının dayandığı temel varsayım, tüm borç/özkaynak bileşimlerinde borçların maliyetinin aynı olduğudur (Aydın vd., 2015: 284). Ancak özkaynak sağlayanların getiri beklentileri işletmenin borç/özkaynak oranı arttıkça artmaktadır (Sayılgan, 2019: 334).

Geleneksel Yaklaşım: Yöneticilerin kaynak kullanımından yararlanarak belirli bir sermaye yapısı oluşumuna kadar şirket değerini artırabileceğinin öne sürüldüğü (Karadeniz vd., 2016: 41) geleneksel yaklaşım, işletmeler açısından tek bir optimal sermaye yapısının varlığını, işletmelerin finansal kaldıraçtan faydalanarak, ağırlıklı ortalama sermaye maliyetini düşürüp, piyasa değerini yükseltebileceği varsayımına dayanmaktadır (Aydın vd., 2015: 288). Bu yaklaşıma göre borçlanma sonsuz değildir ve belli bir noktadan itibaren borç düzeyindeki artış firmanın değerini azaltmaktadır (Ercan ve Ban, 2018: 233). Geleneksel yaklaşımın optimal sermaye yapısının oluşturulması açısından günümüz koşullarında daha rasyonel varsayımlara dayandığı söylenebilmektedir.

Dengeleme Teorisi: Hedef borç oranlarının işletmeden işletmeye değişeceğini kabul eden dengeleme kuramı, işletmenin borç-özkaynak seçimini, borçlanmanın sağladığı avantaj ile neden olduğu dezavantaj arasında bir denge noktasında yer alması gerektiğini iddia eder (Okuyan ve Taşçı, 2010:107). Öte yandan, dengeleme teorisi, duran varlıkları yüksek olan işletmelerin iflas etme risklerinin düşük olması sebebiyle daha rahat borçlanabileceklerini öngörmektedir (Terim ve Kayal1, 2009: 136).

Finansal Hiyerarşi Kuramı (Pecking Order Theory): Finansal hiyerarşi teorisine göre, işletmeler kaynak ihtiyacı durumunda ilk olarak dağıtılmamış karlar, ardından borçlar ve son olarak hisse senedi ihracını kullanmaktadır (Gülşen ve Ülkütaş, 2012:50). Finansal hiyerarşi optimum sermaye yapısı olarak, ortalama sermaye maliyetini en aza indirgeyecek bir borç düzeyinden ziyade finansal esnekliği korumayı hedef almaktadır (Otluoğlu, 2016:20). 


\section{LITERATÜRDEKİ ÇALIŞMALAR}

Bu bölümde, sahiplik ve sermaye yapısı kavramı çerçevesinde, araştırmamıza hem dayanak sağlayacak hem de bu alanda yapılmış çalışmalar hakkında bilgi verecek literatürde öne çıkan bazı çalışmalar değinilmiştir.

Sermaye yapısının yatırım kararları üzerindeki etkisini inceleyen Zhang (1998), bir firmanın sahiplik yapısının, finansal kaldıracı artırıcı etkisi olduğunu belirtmiştir. Yapılan çalışma özkaynak finansmanının yatırım eksikliğine neden olabileceğini, ancak borç ve özkaynak birleşimiyle bir sermaye yapısının benimsenmesinin yatırımın finansman problemini ortadan kaldırırken yatırımın verimliliğini artırabileceğini göstermektedir. Benzer şekilde King ve Santor (2008), aile sahipliğinin 613 Kanadalı firmanın 1998-2005 y1lları arasında performansını ve sermaye yapısını nasıl etkilediğini incelemektedir. Aktif karlılığa ve finansal kaldıraca dayalı Tobin's Q oranları ile analiz sonuçları aile sahipliği yoğun olan firmaların, diğer firmalara benzer piyasa performansı sergilediğini göstermektedir.

Marchica (2008), blockholding ve yönetim kurulu tarafından oluşan sahiplik yapısının borç yapısında önemli belirleyici bir faktör olduğunu vurgulamaktadır. Yazar, hissedarların kimliği ne olursa olsun, ister blockholding ister yönetim kurulu açısından istatistiksel olarak incelendiğinde negatif bir ilişki olduğu sonucuna varmıştır. Başka bir bakış açısıyla Margaritis ve Psillaki (2008) sermaye yapısı ile sahiplik yapısını inceledikleri makalelerinde, özellikle sahiplik yapısının sermaye yapısı ve firma performansı üzerindeki etkisini analiz etmişlerdir. Çalışmada, borçlanma biçimleri ile sahiplik yapısı arasında aynı yönlü bir ilişki olduğu görülmüştür. İşletmeyi değerlendirmek ve işletme performansını takip edebilmek ve dolayısıyla vekalet maliyetlerini en aza indirebilmek amacıyla borçlanma yoluyla finansmanı destekledikleri sonucuna varılabilmektedir.

Arosa vd. (2010) sahip olma yoğunluğunun çoğunluk ve azınlık hissedarları arasındaki çatışmaya odaklanarak, şirket performansını nasıl etkilediğine ve verileri kullanarak aile ve aile şirketlerinin davranışları arasındaki farklılığa neden olduğuna dair yeni kanıtlar sunmaktadır. Sahiplik yoğunluğunun fazla olduğu şirketlerde, bu durumun firma performansı üzerinde pozitif etkisi davranışların neden olduğu farklılığı açıklayabilmektedir.

Araştırmamıza yön verecek şekilde Bayrakdaroğlu (2010) bağımlı değişken olarak Tobin's Q, Aktif Karlılık, Özkaynak Karlılığı, bağımsız değişken olarak ise en büyük ortağın sermaye payı, en büyük üç ortağın sermaye payı, en büyük beş ortağın sermaye payı, halka açıklık oranı, yabancı payı ve yönetici sahipliğini ele almıştır. 2005 ile 2009 yılları arasında İMKB'de faaliyet gösteren şirketlerin verileri Panel Regresyon Analizine tabi tutulmuştur. Çalışmadan elde edilen sonuçlara göre sahiplik yapısının ele alınan değişkenler kapsamında firmanın finansal performansı üzerinde etkili olduğu ifade edilmiştir. Ancak yabancı payı ve yönetici sahipliği değişkenlerinin finansal performans üzerinde beklenildiğinin aksine etkili olamadığ sonucuna varılmıştır. Öte yandan Şamiloğlu ve Ünlü (2010) ise İMKB 100 Endeksi'nde işlem gören firmalar için sahiplik yapısı ve firma performansı arasındaki ilişkiyi araştırmışlardır. Çalışma, İMKB 100 Endeksine kote olmuş 70 adet firmayı kapsamaktadır. Çalışmanın zaman kısıtı ise 2002 ile 2007 yılları arası olarak belirlenmiştir. Sonuç olarak hem piyasa hem de muhasebe bazlı performans ölçütleri ile sahiplik yapısı arasında istatistiksel olarak anlamlı bir ilişki bulunamamıştır.

Farklı bir teorik yaklaşımla, Okuyan ve Taşçı (2010), Türkiye'de faaliyet gösteren sanayi işletmelerinde optimal sermaye yapısının belirlenmesinde ve işletmelerin borçlanma 
şekillerinin açıklanmasında dengeleme veya finansal hiyerarşi kuramlarından hangisinin daha başarılı olduğunu ortaya koyabilmeyi amaçlamışlardır. Amaç kapsamında yapılan çalışmada sermaye yapısında borç kullanmaya ağırlık veren işletmelerin daha fazla artı değer yaratmasına karşın firmanın kaynaklarını ilk olarak iç fonlardan karşıladıkları; bu fonlar yetmediği takdirde borçlanma yolunu tercih ettikleri konulmuştur. Ele alınan sektör kapsamında finansal hiyerarşi kuramının dengeleme kuramına nazaran daha başarılı olduğu sonucuna ulaşılmıştır.

Ülkelerin kurumsal niteliğini ele alarak Reyna vd. (2012) 2005-2009 yılları arasında Meksika'da bulunan 90 firmanın sahiplik yapısı ve performansları arasındaki ilişkiyi incelenmişlerdir. Elde edilen sonuçlar, sahipliğin Meksika pazarında nasıl yoğunlaştığı konusunda bilgi vermektedir.

Yılgör ve Yücel (2012) ise firma sahiplik yapılarını inceleyerek, söz sahibi ortakların özellikleri ve söz sahibi ortakların oluşturdukları hiyerarşik yapılar hakkında değerlendirmelere yer vermiş ve sahiplik hakkı ile kontrol hakkı ayrımının olup olmadığının belirlenmesini amaçlamıştır. Çalışma sonucunda, firmalarda söz sahibi ortak bulunma düzeyinin yüksek olduğu, hiyerarşik yapıların yaygın şekilde yer aldığı ancak sanılanın aksine karmaşık yapılar oluşturmadıkları saptanmıştır. Söz sahibi ortağın sahiplik hakları ile kontrol haklarının önemli bir şekilde farklılaştığı tespit edilmiştir.

Sayman (2012), tarafından hazırlanan doktora tezinde bir firmanın sahiplik yapısının sermaye yapısına ve firma değerine etkileri incelenmiştir. Ortak sayısı azaldıkça firmaların piyasadaki değerinde artış olduğu ve firmaların sahiplik yapılarının sermaye yapısı kararları üzerinde son derece etkili olduğu ve dolayısıyla sermaye yapısı kararlarının işletme değerlerinde oldukça etkili olduğu sonucuna varılmıştır. Endeks bazında farklılaşmanın söz konusu olduğu ancak benzer sonuçlar elde eden Aytekin ve İbiş, (2014) ise 2009 ile 2012 yılları arasında Borsa İstanbul Metal Eşya, Makina Endeksi'nde işlem görmüş olan 23 adet işletmeyi ele almışlardır. $\mathrm{Bu}$ işletmelerin sahiplik yapılarının finansal performanslarına olan etkilerinin incelendiği çalışmada aktif karlılık, özkaynak karlılığı, Tobin's-Q oranı ile en büyük ortağın sermayedeki payı, en büyük iki ortağın sermayedeki payı, en büyük üç ortağın sermayedeki payı, yabancı payı ve halka açıklık oranı ile ilişkilendirilmiştir. Sonuç olarak sahiplik yapısı değişkenlerinin söz konusu sektörde yer alan işletmelerin finansal performanslarını etkilediğini belirlemişlerdir.

Büyükmert (2015), tarafından hazırlanan yüksek lisans tezinde ise sahiplik bir kavram olarak açıklanmış, sahiplik yapısı ve etkileri finansal boyutu ile ele alınmıştır. İşletmelerin sahiplik yapıları çerçevesinde; sahiplik yoğunlaşması, aile işletmesi, yabancı ortağın payı, holdinge veya bir gruba bağlı olup olmamasının, sermaye yapısı ve kârlılık üzerindeki etkileri incelenmiştir. Uygulamada, 2010 ile 2013 yılları arasında Borsa İstanbul'da faaliyet göstermiş olan 133 işletmenin sahiplik yapıları incelenip, analize dâhil edilmesi için finansal verileri kullanılmıştır. Testler sonucunda, işletmelerin sahiplik yapısının sermaye yapısı üzerinde etkili olduğu, kârlılık üzerinde ise etkisinin olmadığı belirlenmiştir. Öte yandan, Doğan (2016) da sahiplik yapısının firma kararları üzerindeki etkisini inceleyerek 2005 ile 2012 yılları arasında BİST İmalat Sanayi Endeksi'nde hisse senetleri işlem gören 136 firmayı ele almıştır. Yapılan analizler, en büyük ortağın sermayedeki payı, firma büyüklüğü ve aktif karlılığı BİST İmalat Sanayi Endeksi'nde işlem gören işletmelerin alacağı finansal kararda son derece önemli olduğu sonucunu vermiştir. Benzer şekilde Erdoğan, (2016) işletmelerin sahiplik yapılarının, sermaye kararlarına etkilerini incelemek için BİST'te işlem gören 162 işletmeyi ele almıştır. Sahiplik 
yoğunluğu göstergelerinden hâkim sahiplerin ve yönetsel sahiplik kavramının sermaye kararlarını olumlu yönde etkilediği sonucuna varılmıştır.

Shahar vd. (2016), Malezya'daki 38 adet orta büyüklükteki firmanın sermaye yapıları ile sahiplik yapısı ve firma karakterleri arasındaki ilişkiyi 2008-2012 yılları arası veriler alınarak incelemişlerdir. Yüksek sahiplik yoğunluğu ile firmaların borç seviyelerinde önemli farklılıklar olduğu sonucuna varılmıştır. Bir başka bakış açısıyla Ege ve Topaloğlu (2017), Borsa İstanbul 30 Endeksi'nde yer alan firmaların sahiplik yapılarının, temettü politikalarına ve sermaye yapısı kararlarına olan etkisini tespit etmeyi amaçlamışlardır. Ampirik analizler sonucunda 2009 ile 2015 yılları arasında şirketlerin sahiplik yapısı ile sermaye yapısı ve temettü kararları arasında herhangi bir ilişkiye rastlanmamıştır. Bu bağlamda şirketin sahiplik yapısı ile sermaye yapısı ve temettü kararları arasındaki ilişkinin sermaye ve sahiplik yapısından bağımsız gerçekleştiği sonucuna varılmıştır. Son olarak Topaloğlu (2018) tarafından hazırlanan çalışma incelendiğinde 2007 ile 2015 yılları arasında BİST Kurumsal Yönetim Endeksi'nde faaliyet gösteren işletmelerin sermaye yapılarını etkileyen firmaya özgü faktörlerin belirlenmesinin hedeflendiği görülmektedir. Bu kapsamda sermaye yapısı kararlarında etkili olan faktörlerin belirlenmesinde Panel Veri Analiz yöntemi kullanılmıştır. Söz konusu analiz neticesinde, finansal kaldıraç ile likidite oranı, varlık yapısı ve aktif karlılık oranı arasında negatif yönlü ve anlamlı bir ilişki olduğu gözlemlenirken, firma büyüklüğü ile pozitif yönlü bir ilişki tespit edilmiştir. Öte yandan büyüme firsatı, borç dışı vergi kalkanı, faaliyet kaldıracı ve Tobin's Q ile finansal kaldıraç arasında istatistiksel olarak anlamlı bir sonuca ulaşılamamıştır.

\section{VERI SETİ VE METODOLOJI}

BİST Turizm Endeksi'nde yer alan 9 firmanın 2012 ile 2018 yılları arasında Kamu Aydınlatma Platformundan edinilen verilerden faydalanılarak oluşturulan model, sahiplik ve sermaye yapısının firma performansına etkisinin araştırılması amaçlanarak oluşturulmuştur. Söz konusu modelde performans ölçütü olarak ele alınan En Büyük Ortağın Yüzdesel Sahipliği, Stratejik Yatırımcıların Ağırlığı, Toplam Yabancı Kaynak/ Toplam Aktifler ile Toplam Uzun Vadeli Yabancı Kaynak/ Toplam Özkaynak bağımsız değişkenlerinin, Aktif Karlılık (ROA), Özkaynak Karlılığı (ROE), Tobin's Q değerlerine olan etkileri Cari Oran kontrol değişkeni temel alınarak test edilmiştir. BİST Turizm Endeksi'nde yer alan şirketler ve kodları Tablo 1'de gösterilmiştir.

Tablo 1. Analiz Kapsamına Dahil Edilen Şirketler ve BIST Kodları

BIST Kodu

AYCES

AVTUR

MAALT

MARTI

METUR

PKENT

TEKTU

ULAS

UTPYA
Sirket Ad1

Altın Yunus Çeşme Turistik Tesisleri A.Ş.

Avrasya Petrol ve Turistik Tesisler Yatırımlar A.Ş.

Marmaris Altınyunus Turistik Tesisler A.Ş.

Martı Otel İşletmeleri A.Ş.

Metemtur Otelcilik ve Turizm İşletmeleri A.Ş.

Petrokent Turizm A.Ş.

Tek-Art İnşaat Ticaret Turizm Sanayi ve Yatırımlar A.Ş.

Ulaşlar Turizm Yatırımları ve Dayanıklı Tüketim Malları Ticaret Pazarlama

A.Ş.

Ütopya Turizm İnşaat İşletmecilik Ticaret A.Ş. 
Şirketlere ilişkin analizde kullanılan veriler, Borsa İstanbul internet sitesi ve Kamu Aydınlatma Platformu internet sitesinden şirketlerin finansal tablolarına ve faaliyet raporlarına ulaşılarak temin edilmiştir. Araştırmanın amacı doğrultusunda, Borsa İstanbul Turizm Endeksine kote olan 9 şirketin 2012 ile 2018 yılları arasındaki verileri dikkate alınarak, olası sahiplik ve sermaye yapısı etkisi En Küçük Kareler ve Panel Veri Analizi yöntemi kullanılarak ortaya çıkarılmaya çalışılmıştır. Sahiplik yapısının ve finansal kaldıraç derecelerinin finansal performansları üzerindeki etkisini ölçümlemek amacıyla oluşturulan ve analiz kapsamında değerlendirilecek değişkenler yer aldığ 1 Tablo 2'de gösterilmiştir.

\begin{tabular}{|c|c|}
\hline \multicolumn{2}{|l|}{ Tablo 2. Bağımlı, Bağımsız ve Kontrol Değişkenleri } \\
\hline Değișkenler & Kisaltmalar \\
\hline \multicolumn{2}{|l|}{ Bağımlı Değişkenler } \\
\hline Aktif Karlılığı (Net Kar/Toplam Varlıkları) & ROA \\
\hline Özkaynak Karlılığı (Net Kar/Özkaynaklar) & ROE \\
\hline Tobins'Q (Piyasa Değeri+Toplam Borç)/Toplam Varlıklar & TQ \\
\hline \multicolumn{2}{|l|}{ Bağımsız Değişkenler } \\
\hline Uzun Vadeli Yabancı Kaynak / Toplam Özkaynak & UVTÖ \\
\hline Toplam Yabancı Kaynak / Toplam Varlıklar & TYTV \\
\hline Stratejik Ortak & SO \\
\hline $\begin{array}{l}\text { Kukla Değişken (En Büyük Ortağın Şirketin \%50'sinden Fazlasına Sahip } \\
\text { Olması Durumu) }\end{array}$ & $\mathrm{BO}$ \\
\hline \multicolumn{2}{|l|}{ Kontrol Değişkeni } \\
\hline Cari Oran (Dönen Varlıklar/Kısa Vadeli Yabancı Kaynaklar) & $\mathrm{CO}$ \\
\hline
\end{tabular}

Bağımlı değişken olarak kullanılan ve firmanın net karının aktif toplamına bölümüyle elde edilen Aktif karlılık oranıyla, işletmenin varlıkları üzerinden ne kadar gelir sağladığı tespit edilmektedir (Karadeniz ve İskenderoğlu, 2011: 69). Aynı zamanda Aktif Karlılığın en önemli özelliklerinden biri firmanın elde ettiği getiriyi finansal kaldıraç ve vergi yükümlülüğünü dikkate alarak ölçmesidir (Cornett vd., 2016: 57). Benzer şekilde özkaynak karlılığı da net karın özkaynak toplamına oranıyla bulunmakta ve net karın ne kadarının özkaynaklardan elde edildiğini göstermektedir (Bayrakdaroglu, 2010:14). Öte yandan şirket performansı ölçümünde kabul gören bir gösterge olan Tobins'Q oranı firmanın defter-piyasa değerinin bir ölçüsüdür (Min ve Prather, 2001:269). Borsa İstanbul Turizm Endeksi'nde yer alan firmaların sahiplik yapısının ve finansal kaldıraç derecelerinin (Toplam Yabancı Kaynak / Toplam Varlıklar) finansal performansları üzerindeki olası etkilerinin incelenmesi amacı doğrultusunda Aktif Karlılık, Özkaynak Karlılığı ve Tobin's Q değişkenlerinin değerlendirilmesi için oluşturulan 3 model şu şekildedir.

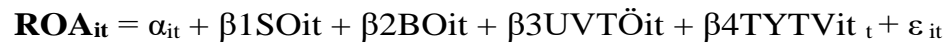

ROE $_{i t}=\alpha_{i t}+\beta 1$ SOit $+\beta 2$ BOit $+\beta 3$ UVTÖit $+\beta 4$ TYTVit $_{t}+\varepsilon_{\text {it }}$

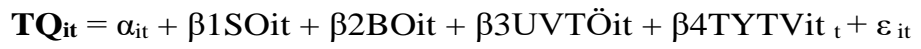

$\mathbf{H}_{\mathbf{0}}=$ Şirketlerin Sermaye Yapısı ve Sahiplik Yapısının finansal performansları üzerinde bir etkisi yoktur. 
$\mathbf{H}_{1}=$ Şirketlerin Sermaye Yapısı ve Sahiplik Yapısının finansal performansları üzerinde bir etkisi vardır.

Bağımsız değişkenlerde istatistiksel olarak anlamlı bir sonuç ortaya çıkması halinde $\mathbf{H}_{\mathbf{0}}$ hipotezi reddedilecektir.

\section{ANALIZLER VE BULGULAR}

Çalışmada performans ölçümünde kullanılması planlanan bağımlı (Aktif Karlılık, Özkaynak Karlılığı ve Tobin's Q) ve bağımsız değişkenler (En Büyük Ortağın Yüzdesel Sahipliği, Stratejik Yatırımcıların Ağırlığı, Toplam Yabancı Kaynak/ Toplam Aktifler ile Toplam Uzun Vadeli Yabancı Kaynak/Toplam Özkaynak) ile kontrol değişkenine (Cari oran) ait betimleyici istatistik verileri incelenerek Tablo 3'te gösterilmiştir.

\begin{tabular}{|l|l|l|l|l|l|l|l|}
\hline \multicolumn{7}{|c|}{ Tablo 3. Değişkenlere Ait Betimleyici İstatistik Verileri } \\
\hline & ROA & ROE & TQ & SO & UVTÖ & TYTV & CO \\
\hline Ortalama & 1.867 & 3.089 & 0.941 & 0.564 & 2.381 & 2.534 & 2.459 \\
\hline Medyan & -0.33 & -1.080 & 0.761 & 0.478 & 2.014 & 1.296 & 0.97 \\
\hline Max. & 4.832 & 1.424 & 2.658 & 0.919 & 8.042 & 1.290 & 1.755 \\
\hline Min. & -2.117 & -3.565 & 0.072 & 0.339 & 0.078 & 2.450 & 0.22 \\
\hline Std. Sapma & 1.242 & 2.043 & 0.529 & 0.216 & 2.215 & 2.673 & 3.750 \\
\hline Çarpıklık & 1.653 & 5.241 & 1.178 & 0.689 & 0.578 & 1.423 & 2.520 \\
\hline Basıklık & 7.498 & 3.888 & 4.287 & 1.950 & 2.243 & 5.169 & 8.789 \\
\hline Jarque-Bera & 8.182 & 3.667 & 1.894 & 7.873 & 4.961 & 3.363 & 1.547 \\
\hline Probability & 0.000 & 0.000 & 0.000 & 0.0195 & 0.083 & 0.000 & 0.000 \\
\hline Gözlem & 63 & 63 & 63 & 63 & 63 & 63 & 63 \\
\hline
\end{tabular}

Gözlem sayısının 63 olduğu veri setinin incelendiği Tablo 3'te normal dağılımın varlığı ve anlamlılık dereceleri Jarque-Bera testiyle incelenmiştir. Çalışma kapsamında kullanılan bağımlı ve bağımsız değişkenlere ait betimleyici istatistiksel verileri ele alınan değişkenler için ortalama, medyan, maksimum, minimum, standart sapma değerleri ile araştırmada kullanılan serilerin çarpıklık ve basıklık dereceleri tespit edilmiştir.

\begin{tabular}{|l|l|l|l|l|l|l|l|l|}
\hline \multicolumn{7}{|c|}{ Tablo 4. Kullanılan Değişkenlere Ait Korelasyon Matrisi } \\
\hline & ROA & ROE & TOBIN & SO & UVTÖ & TYTV & CO & \\
\hline ROA & 1 & & & & & & & \\
\hline ROE & 0.658375 & 1 & & & & & & \\
\hline TOBIN & -0.13928 & -0.15237 & 1 & & & & & \\
\hline SO & 0.024428 & -0.03836 & 0.323058 & 1 & & & & \\
\hline UVTÖ & -0.19142 & -0.11345 & -0.0209 & -0.35781 & 1 & & & \\
\hline TYTV & -0.2533 & -0.16776 & -0.16669 & -0.48937 & 0.609719 & 1 & & \\
\hline CO & 0.330504 & 0.282246 & 0.099214 & -0.01094 & -0.27065 & -0.15385 & 1 & \\
\hline
\end{tabular}

Değişkenlerin arasında muhtemel bir yüksek korelasyon varlığının kullanılan veri seti ve modelin açıklama gücünü etkileme olasılığg ile oluşturulan korelasyon matrisine Tablo 4'te yer verilmiştir. Elde edilen sonuca göre değişkenler arasında hem pozitif hem de negatif yönde aşırı yüksek korelasyonun var olmadığ görülmüştür.

Korelasyon matrisi incelendikten sonra, Havuzlanmış En Küçük Kareler Yöntemi ile bütün veriler bir havuzda toplanarak, bağımlı değişkenlerin bağımsız değişkenlerden ne ölçüde etkilendikleri Aktif Karlılık (ROA) bağımlı değişkeni için Tablo 5, Özkaynak Karlılı̆̆ı (ROE) 
bağımlı değişkeni için Tablo 6 ve Tobins'Q bağımlı değişkeni için Tablo 7'de ortaya konulmaktadır.

Tablo 5. Havuzlanmış OLS Testi ROA Bağımlı Değişken Sonuçları

\begin{tabular}{|l|c|c|c|}
\hline & \multicolumn{3}{|c|}{ ROA } \\
\hline Kat Sayı & T-İstatistiği & P-Değeri \\
\hline UVTÖ & -9.699 & -0.7778 & 0.4399 \\
\hline TYTV & 0.1011 & 0.8396 & 0.4047 \\
\hline BO & -0.1897 & -1.824 & $0.0734^{*}$ \\
\hline CO & 2.221 & 0.39201 & 0.6965 \\
\hline C & 1.157 & 2.313 & $0.0244^{* *}$ \\
\hline R-Kare & 6.028 & 0.87653 & 0.3845 \\
\hline Düzeltilmiş R-Kare & \multicolumn{4}{|c|}{0.17195} \\
\hline
\end{tabular}

Öncelikle Tablo 5 incelendiğinde Aktif Karlılık (ROA) bağımlı değişkeni dikkate alındığında sahiplik ve sermaye yapısı değişkenleri kapsamında TYTV (Toplam Yabancı Kaynak / Toplam Varlıklar) bağımsız değişkeninin ROA bağımlı değişken üzerinde negatif yönde ve \%10 düzeyinde anlamlı etkiye sahip olduğu sonucuna varılmıştır. Kontrol değişken olan Cari Oran (CO)'nın ise $\% 5$ düzeyinde pozitif yönde etkiye sahip olduğu gözlemlenmiştir. Kukla değişken temelinde bakıldığında ROA bağımlı değişken üzerinde pozitif etkisi olduğu; ancak bunun anlamlı bir etki olmadığ 1 sonucuna varılmıştır.

Tablo 6. Havuzlanmış OLS Testi ROE Bağımlı Değişken Sonuçları

\begin{tabular}{|l|c|c|c|}
\hline & \multicolumn{3}{|c|}{ ROE } \\
\hline & Kat Sayı & T-İstatistiği & P-Dĕgeri \\
\hline SO & -3.889 & -1.901 & $0.0624^{*}$ \\
\hline UVTÖ & 1.637 & 0.8286 & 0.4108 \\
\hline TYTV & -2.713 & -1.594 & 0.1163 \\
\hline BO & 1.546 & 1.665 & 0.1013 \\
\hline CO & 2.208 & 2.743 & $0.008^{* * *}$ \\
\hline C & 1.465 & 1.317 & 0.1928 \\
\hline R-Kare & \multicolumn{4}{|l|}{} \\
\hline Düzeltilmiş R-Kare & 0.16175 & 0.08822 \\
\hline
\end{tabular}

ROE bağımlı değişkeni için Tablo 6 değerlendirildiğinde, Stratejik Ortak (SO) negatif yönde ve \%10 düzeyinde anlamlı etkiye sahiptir. Kontrol değişken olan Cari Oran (CO) üzerinde etkisi pozitif yönde ve \%1 düzeyinde anlamlıdır.

Tablo 7. Havuzlanmış OLS Testi Tobins'Q Bağımlı Değişken Sonuçları

\begin{tabular}{|l|c|c|c|}
\hline & \multicolumn{3}{|c|}{ Tobins'q } \\
\hline & Kat Sayı & T-İstatistiği & P-Değeri \\
\hline SO & 1.373 & 2.637 & $0.010^{* * *}$ \\
\hline UVTÖ & 0.00912 & 1.813 & $0.075^{*}$ \\
\hline TYTV & -0.00552 & -1.274 & 0.2075 \\
\hline BO & -0.35530 & -1.502 & 0.1384 \\
\hline CO & 0.00661 & 0.3226 & 0.7482 \\
\hline C & 0.19095 & 0.6745 & 0.5027 \\
\hline R-Kare & \multicolumn{4}{|l|}{} \\
\hline Düzeltilmiş R-Kare & 0.18944 & 0.11834 \\
\hline
\end{tabular}


Tablo 7'de Tobin's Q bağımlı değişkenini dikkate alarak gerçekleştirilen Havuzlanmış OLS testi sonuçları gösterilmektedir. Elde edilen bulgulara göre diğer iki değişkenden farklı olarak SO pozitif ve \%1 düzeyinde etkilidir. Ayrıca Uzun Vadeli Yabancı Kaynak/Toplam Varlıklar (UVTÖ) oranı istatistiksel olarak pozitif ve \%10 anlamlıdır. Öte yandan, TVTY ve BO değişkenlerinin TOBINS'Q değişkeni üzerinde negatif fakat bir etkisi olduğu fakat bu etkinin anlamlı olmadığ 1 sonucuna ulaşılmıştır.

Analize dâhil edilen tüm firmaların aynı olduğu ön kabulünü varsayan Havuzlanmış En Küçük Kareler (OLS) Tekniğinde sonuçların güvenirliğinin kuşku yaratabileceği düşünülmekle birlikte, firmaları hem zaman hem de veri boyutunda farklı bir şekilde değerlendirmesine imkan tanıyan Panel Veri Analizi uygulanmıştır. Modellerde sabit etkilerin mi yoksa rassal etkilerin mi baskın olduğunun belirlenebilmesi için Hausman Testinin kullanılması uygun görülmüştür.

Tablo 8. Hausman Testi Sonuçları

\begin{tabular}{|l|c|c|c|}
\hline & ROA & ROE & Tobins'q \\
\hline Chi-Sq. İstatistiği & 9.5894 & 11.6968 & 1.6812 \\
\hline P-Değeri & 0.147 & 0.288 & 0.641 \\
\hline
\end{tabular}

Tablo 8'de yer alan Hausman Testi sonuçlarına göre üç modele göre rassal etkiler modelinin uygulanabilirliği konusunda anlamlı sonuçlar elde edilmiştir.

Tablo 9, Tablo 10 ve Tablo 11'de Rassal Etkiler Modelinde her firmanın kendisine özgü olduğu düşünülerek bağımsız değişkenler üzerinden açıklanmasının daha uygun olacağı düşünülmektedir.

Tablo 9. Rassal Etkiler Modeli ROA Bağımlı Değişken Sonuçları

\begin{tabular}{|c|c|c|c|}
\hline & \multicolumn{3}{|c|}{ ROA } \\
\hline & Kat Sayı & T-İstatistiği & P-Değeri \\
\hline SO & -9.699 & -0.8051 & 0.4242 \\
\hline UVTÖ & 0.1011 & 0.8690 & 0.3885 \\
\hline TYTV & -0.1897 & -1.888 & $0.0641 *$ \\
\hline BO & 2.221 & 0.40574 & 0.6865 \\
\hline $\mathrm{CO}$ & 1.157 & 2.394 & $0.024 * *$ \\
\hline $\mathrm{C}$ & 6.028 & 0.9072 & 0.3682 \\
\hline R-Kare & & 0.1720 & \\
\hline Düzeltilmiş R-Kare & & 0.0832 & \\
\hline
\end{tabular}

Tablo 9'da elde edilen verilerin neticesinde, TYTV (Toplam Yabancı Kaynak/Toplam Varlık) bağımsız değişkeninin Aktif Karlılık (ROA) bağımlı değişkeninde negatif yönde ve \%10 düzeyinde anlamlı etkiye sahiptir. $\mathrm{CO}$ kontrol değişkenin ise $\% 5$ düzeyinde pozitif yönde etkiye sahip olduğu tespit edilmiştir. Kukla değişken (BO) temelinde bakıldığında ROA bağımlı değişken üzerinde pozitif etkisi olmasına karşın bu etkinin anlamlı olmadığı sonucuna varılmıştır.

Tablo 10. Rassal Etkiler Modeli ROE Bağımlı Değişken Sonuçları

\begin{tabular}{|l|c|c|c|}
\hline & \multicolumn{3}{|c|}{ ROE } \\
\hline & Kat Sayı & T-İstatistiği & P-Dĕgeri \\
\hline SO & -4.331 & -2.043 & $0.045^{* *}$ \\
\hline UVTÖ & 1.682 & 0.9029 & 0.3704 \\
\hline TYTV & -3.161 & -1.959 & $0.055^{*}$ \\
\hline BO & 1.662 & 1.730 & $0.089^{*}$ \\
\hline
\end{tabular}




\begin{tabular}{|l|c|c|c|}
\hline CO & 2.315 & 2.929 & $0.004 * * *$ \\
\hline C & 1.752 & 1.519 & 0.1341 \\
\hline R-Kare & \multicolumn{3}{|c|}{0.17715} \\
\hline Düzeltilmiş R-Kare & 0.10497 \\
\hline
\end{tabular}

Öte yandan ROE bağımlı değişkeni kapsamındaki analiz sonucuna göre, bağımsız değişken Stratejik ortak (SO) negatif yönde ve $\% 5$ düzeyinde anlamlı etkiye sahiptir. Kontrol değişken olan Cari Oran (CO) üzerinde etkisi pozitif yönde ve \%1 düzeyinde anlamlıdır. Ayrıca TYTV (Toplam Yabancı Kaynak/Toplam Varlık) bağımsız değişkeninin Özkaynak Karlılığı (ROE) bağımlı değişkeninde negatif yönde ve \%10 düzeyinde anlamlı etkiye sahip olduğu sonucuna ulaşılmıştır.

Tablo 11. Rassal Etkiler Modeli Tobins'Q Bağımlı Değişken Sonuçları

\begin{tabular}{|l|l|l|l|}
\hline & \multicolumn{3}{|c|}{ Tobins'q } \\
\hline & Kat Sayı & T-İstatistiği & P-Değeri \\
\hline SO & 2.146 & 1.553 & 0.1258 \\
\hline UVTÖ & 0.0111 & 2.869 & $0.005^{* * *}$ \\
\hline TYTV & -0.0002 & -0.0567 & 0.9550 \\
\hline BO & -0.5889 & -0.9424 & 0.3500 \\
\hline CO & -0.0150 & -0.7710 & 0.4439 \\
\hline C & -0.2965 & -0.4270 & 0.6710 \\
\hline R-Kare & \multicolumn{3}{|}{} \\
\hline Düzeltilmiş R-Kare & 0.1965 \\
\hline
\end{tabular}

Son olarak Tablo 11 Rassal Etkiler Modeli Tobins'Q bağımlı değişken sonuçları incelendiğinde, Tablo 10 ile benzer sonuçlar elde edilmektedir. Uzun Vadeli Yabancı Kaynak/Özkaynak (UVTÖ) bağımsız değişken ile Tobins'Q bağımlı değişkenin ilişkisi istatistiksel olarak pozitif ve \%1 anlamlı olmasına karşın, Tobin's Q bağımlı değişkeninde Sratejik Ortak (SO) bağımsız değişkeninin Havuzlanmış En Küçük Kareler Yöntemi (OLS) testi sonucundaki pozitif ve istatistiksel olarak anlamlılığın rassal etkiler modelinde kaybolduğu görülmektedir.

\section{SONUÇ}

İşletmelerin firma değerini maksimize etme amaçları doğrultusunda özellikle sermaye yapısının firma üzerindeki etkilerinin önemi tartışılmaz bir gerçektir. Zira sermaye yapısı hissedarların çıkarlarını gözetme hususunda da hayati önem taşımakla birlikte, firmanın sağlayacağı kaynakların ve bu kaynakların maliyetlerinin belirlenmesinde de büyük rol oynamaktadır.

Bir firmanın kaynak maliyetlerinin belirlenmesi, sermaye maliyetinin oluşturulması anlamına gelmekle birlikte, oluşturulan sermaye maliyeti muhtemel ortakların ve yatırımcıların yanı sıra borç sağlayıcılar açısında da son derece belirleyici bir unsur olmaktadır. Sermaye yapısına ilave olarak bir firmada belirleyici bir diğer unsur da sahiplik yapısıdır. Özellikle işletmenin karlılığı ve rekabet üstünlüğü açısından ortakların vereceği kararlar firmanın piyasa değerinin artırılması hususunda büyük önem arz etmektedir. Dolayısıyla sermaye yapısı ve sahiplik yapısı birbirinden ayrılmaz iki önemli husus olarak ele alınmalı ve özellikle firma performansı değerlendirmesi söz konusu olduğunda olası etkiler birlikte değerlendirilmelidir. Bu bağlamda, çalışmanın amacı kapsamında firmaların sahiplik ve sermaye yapılarının firma performansı üzerinde etkili olduğu varsayımına dayanarak, şirketlerin iç dinamikleri ve piyasa katılımcıları açısından firma değerinin belirlenebilmesi ya da bu değer üzerine etki eden faktörlerin 1582 
tespitinin büyük önem taşıdığı düşünülmektedir. $\mathrm{Bu}$ düşünce doğrultusunda yapılan araştırmada 2012 ile 2018 yılları arasında BİST Turizm Endeksi'nde faaliyet gösteren 9 firmanın performanslarının belirlenmesi açısından bağımlı değişkenler (Aktif Karlılık, Özkaynak Karlılığı ve Tobins' Q), bağımsız değişkenler (En Büyük Ortağın Yüzdesel Sahipliği, Stratejik Yatırımcıların Ağırlığı, Toplam Yabancı Kaynak/ Toplam Aktifler ile Toplam Uzun Vadeli Yabancı Kaynak/ Toplam Özkaynak) ve kontrol değişkeni olarak Cari Oran ele alınıp bir veri seti oluşturulmuştur. Oluşturulan veri setinde değişkenlere ait betimleyici istatistik verileri değerlendirildikten sonra, değişkenlerin korelasyon matrisi alınmıştır. Ortaya çıkan sonuca göre değişkenler arasında yüksek korelasyonun var olmadığı tespit edilmiştir. Akabinde, üç bağımlı değişken için uygulanan Havuzlanmış En küçük Kareler (OLS) Tekniği ile analize konu olan tüm firmaların aynı olduğu kabul edilmiş olup güvenilir bir sonuç elde edilmek amacıyla kullanılan modellerin her ikisi için de firmaları hem zaman hem de veri boyutunda farklı bir şekilde değerlendirmeye imkân tanıyan Panel Veri Analizi yöntemi kullanılmıştır. Uygulanan Hausman Testi ile modellerde sabit etkilerin mi yoksa rassal etkilerin mi daha baskın olduğu tespit edilmiştir.

Uygulanan test sonucu üç modele rassal etkiler modelinin uygulanabilirliği sonucuna varılmıştır. Rassal etkiler modelinde üç bağımlı değişkenin, bağımsız değişkenler üzerindeki etkilerinin yönü ve anlamlılık dereceleri tespit edilmiştir. Nihai olarak bakıldığında BİST Turizm Endeksi'nde yer alan 9 firmanın sahiplik yapısının ve finansal kaldıraç derecelerinin finansal performansları üzerinde olası etkilerini ortaya çıkarmak amacıyla yapılan çalışmada elde edilen verilerle sahiplik ve sermaye yapısındaki değişkenlerin model bazında farklılaşmasıyla birlikte istatistiksel olarak anlamlı sonuçlar elde edilmiştir. Dolayısıyla bu bulgular $\mathrm{H}_{0}$ hipotezinin veri seti kapsamında reddedilebileceğini işaret etmektedir. Söz konusu elde edilen sonuçlar literatür kapsamında ele alındığında Bayrakdaroğlu'nun 2010 yılında hazırlamış olduğu ve çalışmada bağımlı değişken olarak Tobin's Q, Aktif Karlılık, Özkaynak Karlılığ̣, bağımsız değişken olarak ise en büyük ortağın sermaye payı, en büyük üç ortağın sermaye payı, en büyük beş ortağın sermaye payı, halka açıklık oranı, yabancı payı ve yönetici sahipliğinin ele alındığı çalışma ile örtüşen sonuçlar elde edilmiştir. Söz konusu çalışmada bağımsız değişkenlerin firma performansına etkisinin varlığı Panel Veri Analizi yöntemi ile ispatlanmıştır. Benzer şekilde Aytekin ve İbiş’in 2014 yılında, 2009 ile 2012 yılları arasında Borsa İstanbul Metal Eşya, Makina Endeksi'nde işlem görmüş olan 23 adet işletmeyi baz almışlardır. Aktif karlılık, özkaynak karlılığı, Tobin's-Q oranı ile en büyük ortağın payı, en büyük iki ortağın payı, en büyük üç ortağın payı, yabancı payı ve halka açıklık oranı ile ilişkilendirmişlerdir. Söz konusu bulgularla ilgili sektörde yer alan işletmelerin finansal performanslarını etkilediği sonucu çalışmayı destekler niteliktedir. Sahiplik ve sermaye yapısının firma performansını etkilediği yapılan çalışmalarda doğrulanmaktadır. Ancak Şamiloğlu ve Ünlü'nün 2010 yılındaki bulguları hem piyasa hem de muhasebe bazlı performans ölçütleri ile sahiplik yapısı arasında istatistiksel olarak anlamlı bir ilişki olmadığı yönündedir. Bu bağlamda araştırma sonuçları söz konusu çalışma ile çelişmektedir. Endeks veya sektör bazında yapılacak farklı sonuçların çıkması muhtemel görülen yeni çalışmaların, konu hakkında bilgilerin detaylandırılması ve ilgililer açısından faydalı olabileceği düşünülmektedir. 


\section{KAYNAKÇA}

AROSA, B. ITTURRALDE, T. \& MASEDA. A. (2010). “Ownership Structure and Firm Performance in Non-listed Firms: Evidence from Spain", Journal of Family Strategy, 1: 88-96.

AYDIN, N. BAŞAR, M. \& COŞKUN, M. (2015). Finansal Yönetim. 2. Baskı. Detay Yayıncilik.

AYDIN, N. BAŞAR, M. \& COŞKUN, M. (2017). Finansal Yönetim. 5. Baskı. Detay Yayıncılık.

AYTEKİN, S. \& İBİŞ, A. (2014). "Mülkiyet Yapısının İşletmelerin Finansal Performansı Üzerindeki Etkilerinin Değerlendirilmesi: BISST Metal Eşya, Makine Endeksi (XMEYS)

Üzerinde Bir Uygulama”, Dumlupınar Üniversitesi Sosyal Bilimler Dergisi, Sayı 40.

BAYRAKDAROĞLU, A. (2010). "Mülkiyet Yapısı ve Finansal Performans: İMKB Örneği”, Ekonomi Bilimleri Dergisi, Cilt 2, Say1 2, 2010 ISSN: 1309-8020 (Online).

CORNETT, M. M. ADAIR, T. A. \& NOFSINGER, J. (2016). Finans. (V. SARIKOVANLIK, Çev.) Ankara: Nobel Yayıncılık.

ÇELİK, S. (2018). “T Harfi ile Başlayan Finansal Kavramlar” A. GÜNDOĞDU (Der.), Finansın Temel Kavramları Güncel Örnekler ve Yaklaşımları ile, Gazi Kitabevi, Ankara.

DOĞAN, M, (2016). "Mülkiyet Yapısının Finansal Kararlar Üzerine Etkisi”, Muhasebe ve Finansman Dergisi, Nisan.

ERCAN, M. K. \& BAN, Ü. (2018). Değere Dayalı İşletme Finansı Finansal Yönetim, 10. Bask1, Gazi Kitabevi.

ERDOĞAN, E. O. (2016). "Temsil Teorisi Çerçevesinde Sahiplik Yapısının İşletmelerin Sermaye Yapısı Kararlarında Etkisi, BİST Uygulaması", Süleyman Demirel Üniversitesi Sosyal Bilimler Enstitüsü Dergisi, (2), Sayı 24: 159-181.

EGE, İ. \& TOPALOĞLU, T. N. (2017). "Sahiplik Yapısı ile Sermaye Yapısı ve Kar Payı Dağıtım Kararları Arasındaki İlişkinin Borsa İstanbul 30 Endeksi’nde Test Edilmesi”, International Conference On Eurasian Economies. Session 3B: Finans I: 254-261.

GÜLŞEN, A. Z. \& ÜLKÜTAŞ Ö. (2012). "Sermaye Piyasasının Belirlenmesinde Finansman Hiyerarşisi Teorisi ve Ödünleşme Teorisi: İMKB Sanayi Endeksi'nde Yer Alan Firmalar Üzerine Bir Uygulama”, ZKÜ Sosyal Bilimler Dergisi, Cilt 8, Sayı 15: 49-59.

KARADENIZ, E. \& İSKENDEROĞLU, Ö. (2011). “İstanbul Menkul Kıymetler Borsası’nda İşlem Gören Turizm İşletmelerinin Aktif Karlılığını Etkileyen Değişkenlerin Analizi” Anatolia. Turizm Araştırmaları Dergisi, 22 (1):65-75.

KARADENIZ, E. KAPLAN, F. \& GÜNAY, F. (2016). "Sermaye Yapısı Kararlarının Karlılığa Etkisi: Borsa İstanbul Turizm Şirketlerinde Bir Araştırma”, Seyahat ve Otel İşletmeciliği Dergisi, Journal of Travel and Hospitality Management, 13 (3): 38-55. 
KILIÇ, M. \& AYÇIRAY, U. (2018). "Yönetim Kurulu ve Sahiplik Yapısının Finansal Performans Üzerindeki Etkisi: BIST İmalat Sanayi Sektöründe Bir Alan Araştırması", Afyon Kocatepe Üniversitesi Sosyal Bilimler Dergisi, 20(2): 177-192.

KING, M. R. \& SANTOR, E. (2008). "Family Values: Ownership Structure, Performance and Capital Structure of Canadian Firms", Journal of Banking\&Finance, 32(11): 2423-2432.

MARCHIA, T. M. (2008). "On The Relevance of Ownership Structure in Determining The Maturity of Debt” Manchester Business School Working Paper, No. 547.

OKUYAN, H. A. \& TAŞÇI, H. M. (2010). “Sermaye Yapısının Belirleyicileri: Türkiye'deki En Büyük 1000 Sanayi İşletmesinde Bir Uygulama”, BDDK Bankalar ve Finansal Piyasalar, 4(1): 105-120.

OTLUOĞLU, E. (2016). Asimetrik Bilgi ve Sermaye Yapısı Kararları: Borsa İstanbul Üzerine Bir Uygulama, İktisadi Araştırmalar Vakfi, İstanbul.

ÖNEM, H. B. \& DEMIR, Y. (2015). "Mülkiyet Yapısının Firma Performansına Etkisi: BİST İmalat Sektörü Üzerine Bir Uygulama”, Süleyman Demirel Üniversitesi Vizyoner Dergisi, 6(13): 31-43.

MARGARITIS, D. \& PSILLAKI, M. (2008). “Capital Structure, Equity Ownership and Firm Performance", Journal of Banking and Finance, 34(3): 621-632.

MIN, H. J. \& PRATHER, J. L. (2001). “Tobin's Q, Agency Conflicts, and Differential Wealth Effects of International Joint Ventures”, Global Finance Journal (12):267-283.

REYNA, J. M. S. M. VAZQUEZ, R. D. \& VALDES, A. L. (2012). “Corporate Governance, Ownership Structure and Performance in Mexico", International Business Research, 5 (11).

SAYMAN, Y. (2012). Sahiplik Yapısının firma Performansı ve Sermaye Yapısı Üzerine Etkileri: İMKB'de İşlem Gören Üretim Firmalarında Bir Uygulama, Doktora Tezi, Ankara Üniversitesi, Sosyal Bilimler Enstitüsü, Ankara.

SHAHAR, H. K. ADZIS, A. A. \& BADERI, N. (2015). “The Relationship Between Ownership Structure, Firm Specific Characteristics and Capital Structure: Evidence from Malaysian Middle-Capital Public Listed Firms", International Journal of Economics and Financial Issues, 6(3): 36-43.

SAYILGAN, G. \& UYSAL, B. (2011). "Türkiye Cumhuriyeti Merkez Bankası Sektörel Borçları Kullanarak Sermaye Yapısını Belirleyen Faktörler Üzerine Bir Analiz:19962008", Ankara Üniversitesi SBF Dergisi, 66 (4): 101 - 124.

SAYILGAN, G. (2019), Soru ve Yanıtlarıyla İşletme Finansmanı, Siyasal Kitabevi, 8. Baskı. Ankara.

ŞAMILOĞLU, F. \& ÜNLÜ, U. (2010)." Sahiplik Yapısı ve Firma Performansı Arasındaki İlişki: İMKB 100 Endeksi Firmaları Üzerine Bir Uygulama”, Muhasebe ve Finansman Dergisi, (46): 66-73. 
TERIM, B. \& KAYALI, C. A. (2009). "Sermaye Yapısını Belirleyici Etmenler: Türkiye'de İmalat Sanayi Örneği”, Celal Bayar Üniversitesi SBF Sosyal Bilimler Dergisi, 7 (1):125- 154.

TOPALOĞLU, E. (2018). "Sermaye Yapısına Etki Eden Firmaya Özgü Faktörlerin Panel Veri Analizleri ile Belirlenmesi: Kurumsal Yönetim Endeksi Üzerine Bir Uygulama”, Finans Politik \& Ekonomik Yorumlar (640) Haziran: 63-100.

YILGÖR, A.G. \& YÜCEL, E. (2012). “İşletmelerin Sahiplik Yapısının İncelenmesi: Sahiplik ve Kontrol Ayrımı Konusunda Çıkarımlar”, Uluslararası Yönetim İktisat ve İşletme Dergisi, 8 (16):41-57.

ZHANG, G. (1998). "Ownership Concentration, Risk Aversion and the Efect of Fnancial Structure on Investment Decisions”, European Economic Review, 42(9): 1751-1778. 